\title{
INVESTIGATION OF EFFECTS OF ORGANIC FERTILIZER PELLET RHEOLOGICAL AND GEOMETRIC PROPERTIES ON MECHANICAL STRENGTH
}

\author{
Antanas Pocius $^{1}$, Egle Jotautiene ${ }^{2}$, Egidijus Zvicevicius ${ }^{2}$, Sigute Savickiene ${ }^{1}$ \\ ${ }^{1}$ Klaipeda State University of Applied Sciences, Lithuania; \\ ${ }^{2}$ Aleksandras Stulginskis University, Lithuania; \\ antan.pocius@gmail.com
}

\begin{abstract}
The main requirement imposed on organic granulated fertilizer as a new product produced from secondary raw material is the possibility to use this product under specific operation conditions determined by environmental factors, static and dynamic loads, mechanical effects, etc. Mechanical strength is considered as the main mechanical property of granulated bulky materials. Organic compost fertilizer pellets as anisotropic materials are characterized by rheological properties, which vary in different directions inside the pellet. The study investigated rheological and strength properties of the newly developed granulated organic fertilizer pellets produced from beef cattle and poultry manure and organic waste compost. As a result, the characteristics of the mechanical properties of the new product, which are characteristic to fragile materials, were presented. Dependencies between pellet deformations and the size of the subjected load depending on the pellet geometrical parameters were determined and presented by mathematical equations with regression coefficients. Test results have shown that the limit strength in vertical and horizontal directions for organic compost pellets with the diameter of $4 \mathrm{~mm}$ and $6 \mathrm{~mm}$, as well as for poultry manure pellet material differed from $10 \%$ to $20 \%$. Pellet mechanical strength depends on their geometric parameters. Given varying deviations of pellet length from the standard sample length, pellet material strength can vary more than $\pm 23 \%$.
\end{abstract}

Keywords: organic fertilizer pellet, rheological and geometric properties, mechanical strength.

\section{Introduction}

The only suitable method of preserving manure as a valuable organic fertilizer is processing by means of granulation. However, in mass production, the technological process has not been fully adjusted. This type of secondary organic raw material processing technologies is widely used and well-known in Europe, USA, Russia, and other countries despite this method of producing organic fertilizer and manure is relatively expensive.

Organic fertilizer is rich in nitrogen, phosphorus, potassium, calcium, and other plant nutrition elements as well as organic material, which has a positive effect on soil properties. Comparing the effect on crop yield, the nutrients contained in manure are slightly behind compared to the same quantity of mineral fertilizers. However, nutrients contained in manure have organic form, and therefore are less washed out of soil, are released into soil gradually through a long period of time without resulting in high concentrations of salts. This not only increases the yield, but also the quality of crops (increased quantities of vitamins, sugar, protein, starch, and no nitrite accumulation). Phosphorus is present in manure in a form of organic compounds, therefore, it practically does not accumulate in a form of iron, aluminum or calcium phosphates, and organic matter are better absorbed by plants during the course of mineralization. For this reason, phosphorus from manure is used better compared to phosphorus contained in mineral fertilizer. Similar situation can be observed with nitrogen. After contact with water, organic manure granules expand increasing their geometric dimensions several times. Given moisture shortage in soil, granules release the moisture gradually thus creating the best conditions for plant roots and microorganisms [1-4].

The main requirement imposed to newly developed organic granulated fertilizers is the possibility to use the under specific operating conditions. Such conditions involve temperature and humidity changes, mechanical stress, static and dynamic loads, etc. Mechanical strength is considered as the main mechanical property of granulated bulky materials. However, in mechanics, this indicator is assessed applying the solid material hypothesis, which says the material is isotropic [5-9].

The new fertilizer pellets developed on the basis of organic compost are attributed to anisotropic materials, the properties of which vary depending on the direction inside the pellet. The main mechanical properties for such materials are considered to be strength and deformations. As a result of external load and changes in environmental thermal regime, distances in a material body between separate particles change and this phenomenon causes body deformation. Fragile materials, to which organic fertilizer pellets are attributed, collapse at low deformations. There are various mechanical 
strength theories known and valid (Galileo, Coulomb, Ponsele's, Mohr's). Currently applied are mechanical and kinetic material strength concepts. Mechanical concept is based on the fact that material decomposition takes place when the body (pellets) loses its strength under the influence of stress. It is assumed a material has a certain limit value of a body mechanical characteristic (stresses, deformations, etc.), at which the body loses strength and disintegrates. The basis for the kinetic concept is the course of the very disintegration process. The main parameters here beside the imposed load are the duration of the load the body is subjected to, and the temperature $[5 ; 7 ; 10 ; 11]$.

When the imposed load on the body (pellet) reaches a critical limit, either a plastic zone or a crack emerges at the sensitive (weakest) place, which eventually develop and increase as the imposed load increases. Another phenomenon related with the emerged or currently present cracks is called fatigue. It is understood as gradual increase in existing crack width subject to cyclically recurring loads. During each cycle of recurring load, the width of the existing crack increases and eventually when the critical limit is reached the body collapses. Taking into account realistic bodies (organic fertilizer pellets in this case) have various defects in their compositions (cracks, material heterogeneity, etc.), a hypothesis was made that the so-called scale (absolute pellet dimensions) effects on pellet strength. The essence of the effect is that pellet strength decreases with increasing the geometric dimensions. Explanation of the scale effect is based on the fact that there is a function of defect distribution existing in material. This leads to a conclusion that the larger material volume unit is affected by a certain load, the greater is the probability of a significant defect in this volume unit, which may accelerate material (pellet) disintegration.

The objective of the research was investigation and identification of pellet mechanical properties of newly developed beef cattle manure-based granulated organic fertilizers based on pellet rheological and geometric characteristics.

\section{Materials and methods}

Beef cattle manure-based granulated organic compost fertilizers produced using a unique technology without the use of binders and mineral supplements, code-named GM-4 and GM-6, and fermented poultry manure fertilizer PMF-5 were selected as the object of the study $[4 ; 6]$.

Pellet moisture levels were determined in accordance with the standard LST EN 14774:2010 and amounted to as follows: $14.9 \pm 0.57 \%$ for pellets $\mathrm{GM}-4,18.6 \pm 0.32 \%$ for pellets $\mathrm{GM}-6$, and $16.4 \pm 0.54 \%$ for pellets PMF-5. Bulk density was determined in accordance with the standard LST EN15103:2010 and amounted to $788.4 \pm 5.8 \mathrm{~kg} \cdot \mathrm{m}^{-3}$ for $\mathrm{GM}-4,770 \pm 4.7 \mathrm{~kg} \cdot \mathrm{m}^{-3}$ for $\mathrm{GM}-6$, and $685.4 \pm 4.3 \mathrm{~kg} \cdot \mathrm{m}^{-3}$ for PMF-5 respectively.

To determine static durability of the pellets, the testing machine Instron 5960 and parameter control and recording system Bluehill were used. The established rate of static load was 1.0 and 10.0 $\mathrm{mm} \cdot \mathrm{min}^{-1}$. The tests were performed compressing pellets in vertical (load direction perpendicular to the pellet's longitudinal axis of symmetry) and horizontal directions. Experimental tests with pellets were repeated 10 times. Research data were processed using mathematical statistical methods. Average values and their confidence intervals $\left(X \pm t_{05} \mathrm{x} S_{x}\right)$ were presented. For determining interconnectivity between the two factors, regression equations were created and the determination coefficient $R^{2}$ was calculated. The reliability of the determination coefficient was assessed given the probability $P_{t}=95 \%$.

Geometrical dimensions of samples (pellets) were measured with the accuracy of $0.01 \mathrm{~mm}$ using a digital micrometer and caliper. Dimensional change of the sample diameter until disintegration threshold of the sample material was measured at static load rate of 1.0 and $10.0 \mathrm{~mm} \cdot \mathrm{min}^{-1}$.

After the material being granulated passes through the granulator's matrix channel and a pellet is formed, the residual internal stresses inside the pellet is the main reason for reduced intermolecular links between the particles of the compressed material. Given the same pressure, the bulk density of the material in the matrix channel is higher than that of the formed pellet. The matrix channel ensures one-time constant pellet deformation in a radial direction of the channel. In a pellet being formed in the matrix channel, potential energy is accumulated resulting in elastic deformation starting inside the pellet when the pellet is no longer subjected to load. Pellet expansion (deformation) in a radial direction leads to reduction of stresses in the pellet side surface layer, which in turn may trigger cracks 
in the material external and internal layers as relaxation processes in the material have not yet ended (Fig. 1).

a)

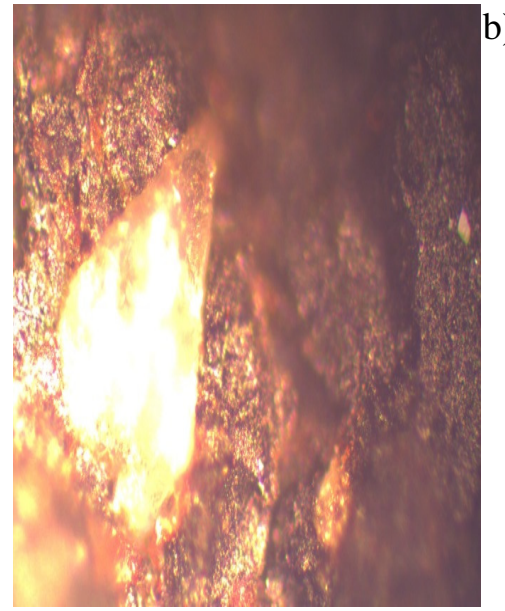

b)

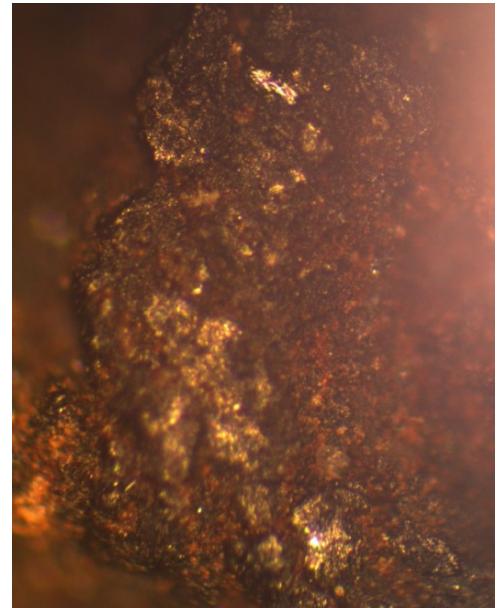

Fig. 1. Structural composition of organic fertilizer GM-4 pellet material:

$\mathrm{a}$ - cross-section; $\mathrm{b}$ - longitudinal section

Elasticity of the pellet material allows for change in its geometrical dimensions and shape after the pellet passes through the matrix channel. Cracks in pellets along the perimeter suggest the material has not been sufficiently compressed, or the time period the pellet is inside the matrix channel subjected to pressure is too short. Suitable for fragile materials and determining mechanical properties thereof is the material compression test. When crushing fragile materials elastic deformations (linear or non-linear) are observed before collapse [4-6]. The deformation character of materials, especially fragile ones, is largely dependent on the friction forces arising on the contact planes of the sample (pellet) and the crushing device support surfaces [5; 7]. In this regard, tests were carried out between the supporting contact surfaces provided dry friction, and reduced friction, with contact surfaces covered with paraffin.

\section{Results and discussion}

Before the load subjected to pellets reached the maximum value, deformation was equally distributed over the length of the pellet. When the load reached the maximum level, deformation was localized in one place. The determined mechanical strength properties of the pellet material were considered to be relative as they were determined without taking into account the pellet cross-sectional area changing during the process of pellet deformation. During the initial stage of pellet deformation these differences were insignificant, i.e. very small, however, when the load was approaching the maximum level, the change in the diameter became noticeable and appeared to be larger given reduced friction between the contact surfaces.

Test results for different pellet lengths have shown that the changes in transverse dimensions when compressing cylindrical test pieces in both vertical and horizontal directions were insignificant. Increase in the diameter before sample disintegration amounted to $3 . .5 \%$. During the test, elastic deformations were observed in the pellets of organic fertilizer before the disintegration, which is characteristic to fragile materials. Correlation between the elastic deformation and stress is nonlinear and does not noticeably meet the Hooke's law.

Figure 2 presents compression correlations for limited plasticity organic fertilizers' GM4, GM6 and PMF-5 pellets. The graph does not show the material density zone and boundary. Pellet disintegration takes place at the graph point. The ordinate of this point shows that the pellet material has limit strength when subjected to compression.

Mechanical properties of granulated compost material determine the pellet capacity to resist to external mechanical effects. The test results have shown that the limit strength of the studied pellet up to the highest static load (highest normal stress) for pellets having different diameter subjected to compression in vertical and horizontal directions differed by $10 \%$ to $20 \%$. The tests with $10 \mathrm{~mm}$ long 
pellets subjected to compression in vertical direction have shown that the limit strength amounted to $430 \mathrm{~N}$ for GM-4 pellets, $145 \mathrm{~N}$ for GM -6 pellets, and $120 \mathrm{~N}$ for PMF -5 pellets.

a)

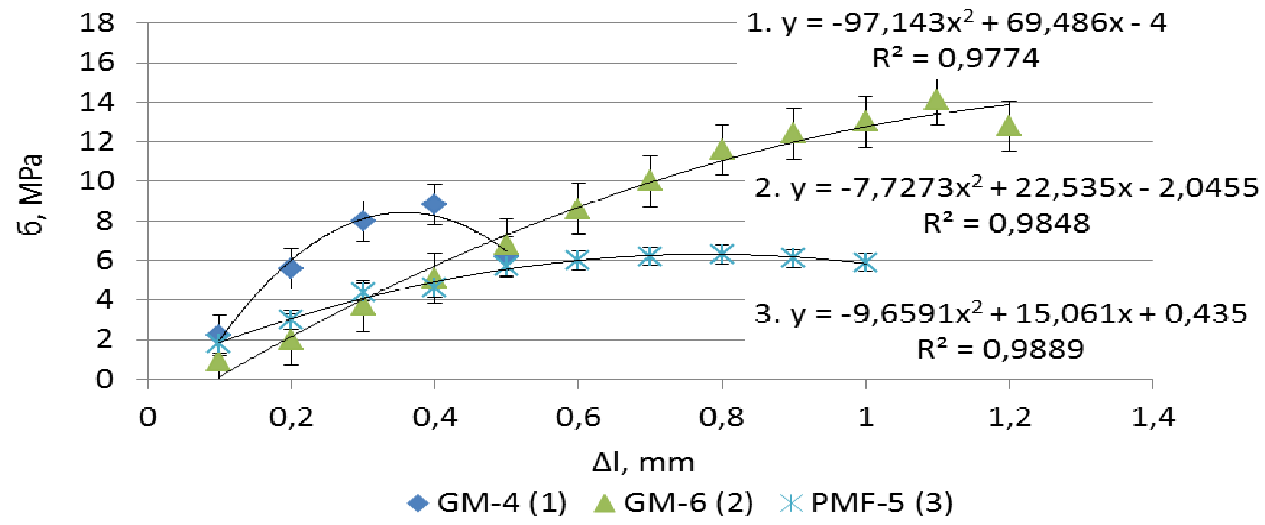

b)

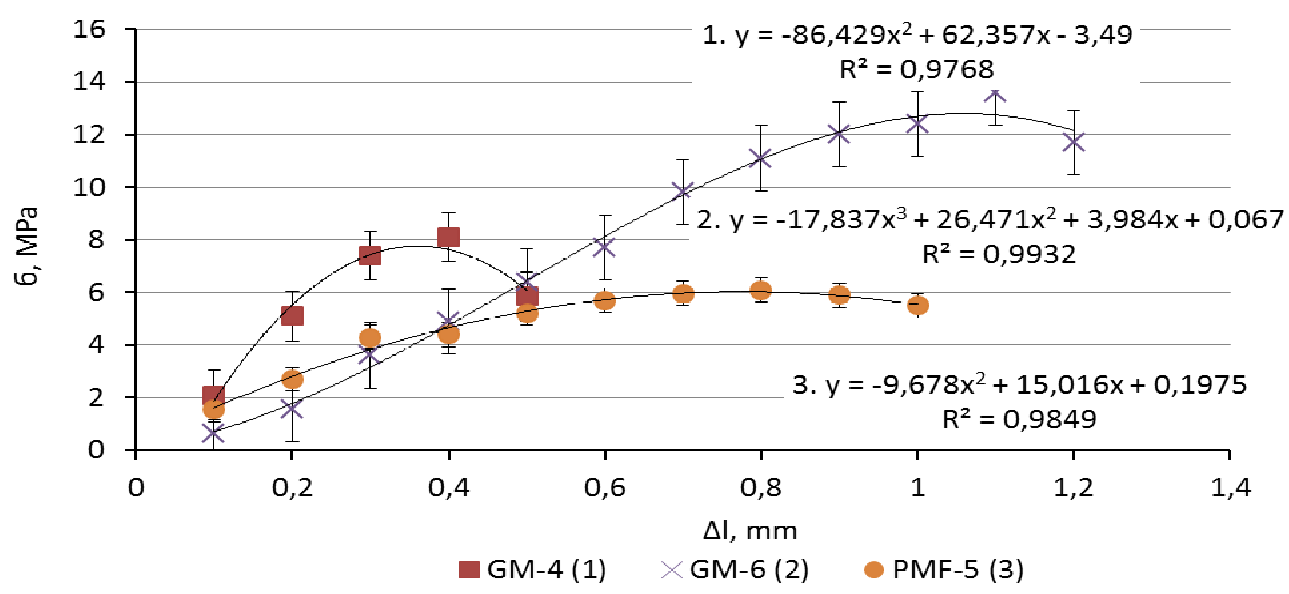

Fig 2. Dependency between pellet deformation $(\Delta \mathrm{I})$ and compressive strength (load):

$a$ - load perpendicular to the pellet's cross section (vertical); $b$ - load parallel to the pellet's cross section (horizontal)

Figure 3 shows that subjected to load the sample geometrical shape has not changed significantly, and following emergence of cracking making a $40-50^{\circ}$ angle with the sample external longitudinal axis of symmetry the sample disintegrates. Such character of the sample cracking direction corresponds to displacement of the rupture planes under the influence of tangential stresses in the material.

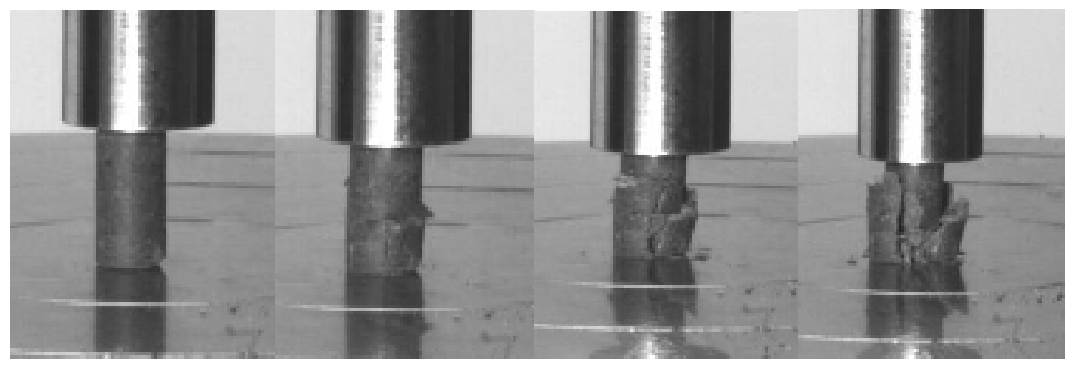

Fig. 3. Course of pellet disintegration

The test results have shown (Fig. 2) that the compression character for all the tested samples was similar and only differed in the size of the compression force before sample disintegration. The character of the compression curves confirmed that the new organic fertilizer pellet material was anisotropic. The tests carried out showed that the tested organic compost pellet strength $(\sigma)$ depends on the pellet length (1), provided the pellet diameter is not subject to change and remains constant (Fig. 4). 


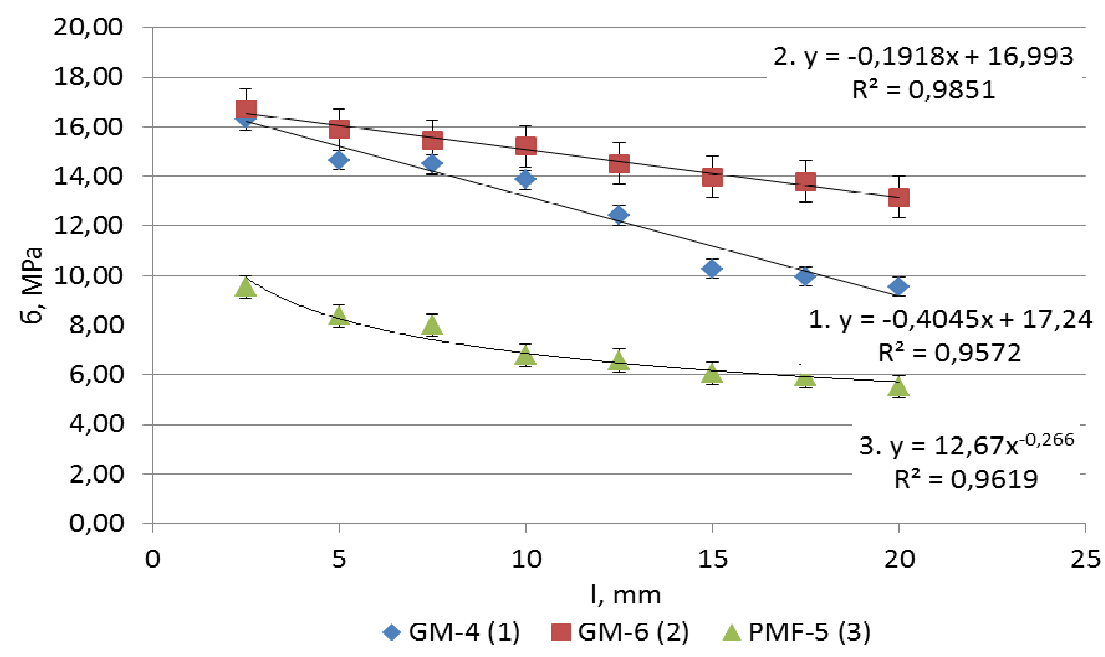

Fig. 4. Dependence of pellet limit strength on sample length

The character of the curve shown on the graph confirmed the scale effect hypothesis that increase in volumetric density of the sample material results in higher probability of defects (cracks) in the material structure, which in turn causes reduction of the pellet strength. The graphs show that given the pellet length interval from $2.5 \mathrm{~mm}$ and $20 \mathrm{~mm}$, the strength of pellets reduces up to $41.46 \%$ for pellets GM-4, up to $21.18 \%$ for pellets GM-6, and up to $42.25 \%$ for pellets PMF-5.

Figure 5 presents the results for organic fertilizer pellet GM-4 compression tests taking into account the friction between the contact surface planes of the sample (pellet) and the operating part of the compression testing machine.

a)

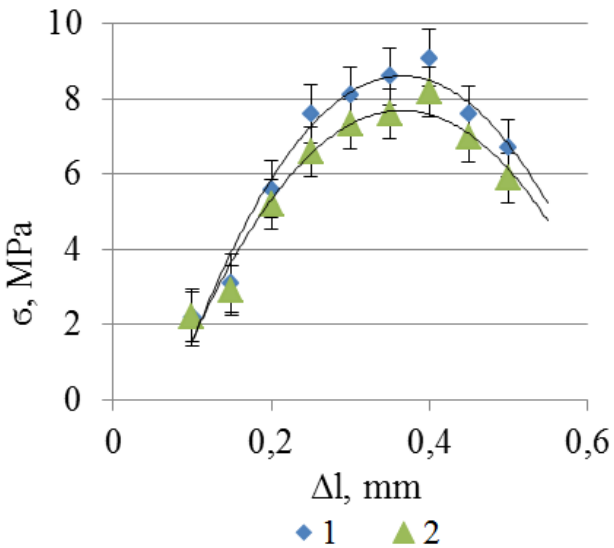

1. $y=100.03 x^{2}+73.182 x-4.7723$;

$R^{2}=0.9614$.

2. $y=-86.364 x^{2}+63.185 x-3.86$;

$R^{2}=0.9596$. b)

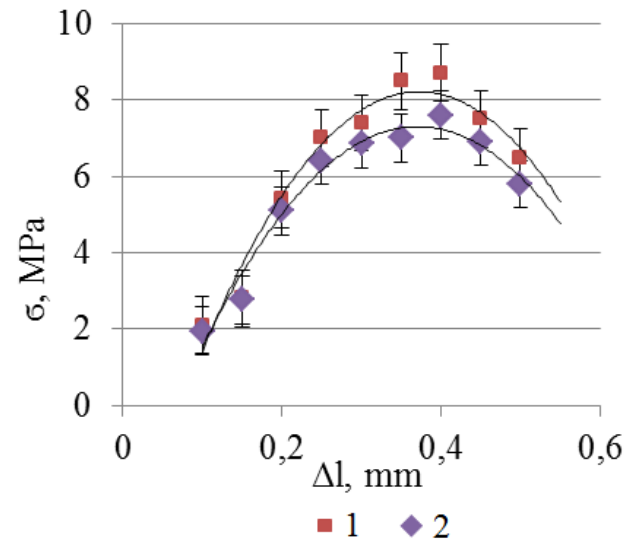

1. $y=-91.515 x^{2}+68.176 x-4.48$;

$R^{2}=0.9575$.

2. $y=-78.662 x^{2}+58.327 x-3.5109$;

$R^{2}=0.9688$

Fig.5. Dependency between pellet GM-4 deformation $(\Delta l)$ and static strength $(\sigma)$ given different types of friction between the contact surfaces: $a$ - dry friction; $b$ - surfaces covered with paraffin; 1 - vertical pellet compression; 2 - horizontal pellet compression

The results have demonstrated that reduced friction resulted in the limit strength of the pellet material reducing by $2.2-3.4 \%$ for vertical compression, and $1.8-2.6 \%$ for horizontal compression. Respective changes in the sample (pellet) disintegration character were also observed.

\section{Conclusions}

1. The test results have shown that the limit strength of the studied pellets up to the highest static load for pellets having different diameter subjected to compression in vertical and horizontal 
directions differed by $10 \%$ to $20 \%$. This shows that the rheological properties of the pellet material vary in pellet longitudinal and transverse directions, which confirms the hypothesis that the compressed organic material is anisotropic.

2. The obtained results have shown that the numerical values of the granulated material disintegration character and mechanical strength properties are influenced by the factor of friction between the contact surfaces of the tested material and the testing device. Given dry or reduced friction the material strength may vary by $3 \%$ to $7 \%$.

3. It has been established that pellet formation kinetics during the technological process of production vary for organic compost having different volumetric dimensions. The pellet material strength in the given interval of the sample lengths $(2.5-20 \mathrm{~mm})$ may vary by up to compared to the standard sample length. Functional dependencies were expressed in $2^{\text {nd }}$ and $3^{\text {rd }}$ degree polynomial equations.

\section{References}

1. Pocius A., Jotautienė E., Butkus V., Jasinskas A. Assessment of brewer's grains utilization technological process and characteristic of the obtained granulated product. Engineering for rural development: 13th International Scientific Conference: proceedings, 2013, Vol. 13, pp. 296-300.

2. Вторичные материальные ресурсы пищевой и перерабатывающей промышленности АПК России и охрана окружающей среды.Справочник (Secondary resources from food production industry in Russian agricultural sector, and environmental protection. A handbook) /Под ред. Е.И. Сизенко. Moskva: Пищепромиздат, 1999. 468 p. (In Russian).

3. Pocius A., Jotautienė E., Pekarskas J., Mieldažys R., Jasinskas A. Research of particle geometrical parameters and aerodynamic features of granular organic compost fertilizers//Engineering for rural development: 13th International Scientific Conference: proceedings, 2014, Vol. 13, pp. 401-406.

4. Pocius A., Jotautienè E., Jasinskas A., Kučinskas V. Investigation of Granulation Process Parameters Influence on the Granulated Fertilizer Compost Properties. Engineering for rural development: 14th International Scientific Conference: proceedings, 2014, Vol. 13, pp. 296-300.

5. Crag R. R. Jr. Mechanics of materials. New York: John Wiley\&Sons, 1996. 722 p.

6. Pocius A., Jotautienė E., Domeika R., Jasinskas A., Kučinskas V., Palšauskas M. Granulation Process Influence of the Granulated Organic Compost Fertilizer Properties. Engineering for rural development: 14th International Scientific Conference: proceedings, 2015. Vol. 14, pp. 829-834.

7. Šiaučiūnas R., Baltakys K., Baltušnikas A. Silikatinių medžiagų instrumentinė analizè (Instrumental analysis of siliceous materials). Kaunas, 2007. 244 p. (In Lithuanian).

8. Назаров В.И., Булатов И.А., Макаренков Д.А. Особенности разработки прессового гранулирования биотоплива на основе растительных отходов (Peculiarities of granulating organic waste for biofuel). Химическое и нефтегазовое машиностроение. 2009, Vol 2. pp. 3539. (In Russian).

9. Jasinskas A., Kučinskas V., Arak M., Olt, J. Research of Physical-Mechanical Properties of Sawdust Fuel Briquettes with the Additives. Rural development 2013: the 6th International Scientific Conference: proceedings, 2013, Vol. 6, book 3, pp. 55-59.

10. Sirvydis J., Dravininkas, A. Dirbtinai džiovintos žolès pašaro ruošimo technologiniai pagrindai (Artificially dried grass forage technological preparation bases.). Kaunas: LŽŪU, 2005. 230 p. (In Lithuanian).

11. Кучинскас 3. М., Особов В. И., Фрегер Ю. Л. Оборудование для сушки, гранулирования и брикетирования кормов (Drying, granulation and briquetting equipment). Moskva: Аргорпомиздат. 1988. 208 p. (In Russian). 